\title{
Analisis Kompetensi Lulusan melalui Kinerja Guru di SMPN Wilayah III Cirebon
}

\author{
Atty Tri Juniarti \\ Fakultas Ekonomi Universitas Pasundan \\ J1. Tamansari No. 6-8, Bandung 40116 \\ E-Mail: tri_1o03@yahoo.com \\ Titien Sukartini \\ Fakultas Pendidikan Dasar Universitas Majalengka \\ J1. K. H. Abdul Halim, No. 103, Kec. Majalengka, Jawa Barat
}

\begin{abstract}
This study examined the phenomenon of graduates competence in SMPN Cirebon Region III. The purpose of this study is to analyze the organization school factors at SMPN Cirebon Region III, the influence of the organization school factors toward teacher competence, the influence of teacher competence toward teacher performance, and the influence of teacher performance to the graduate competence of SMPN Cirebon Region III. The types of this research are descriptive and verification, collection data used the stratified random sampling, the sample size were 266 respondents. The result of study used path analysis show there is an increased activity of primary and secondary education in the Region III Cirebon, marked by the increasing of achieved results, including APK, the average value of the UN, the average of proceed to SLA non RSBI and RSBI. Another result show that there is a closeness relationship between school organizational factors with very low and moderate relationship. Simultaneously, there is significant influence from all organizational of school factors to teachers competence'. Partially, school culture has a dominant influence than others. The last result show there is a significant influence of teachers' competence against the teachers 'performance, and there is significant influence from the teachers' performance against the graduates' competence.
\end{abstract}

Keywords: organizational of school factors, teachers competence, teachers performance, graduates competence.

\begin{abstract}
ABSTRAK
Penelitian ini dilaksanakan atas dasar adanya fenomena menurunnya kompetensi lulusan SMPN Wilayah III Cirebon. Metode penelitian yang digunakan adalah metode deskriptif dan verificatif. Teknik sampling yang digunakan ialah stratified random sampling dengan sampel sebanyak 266 responden. Hasil analisis dengan menggunakan analisis jalur menunjukkan bahwa terdapat peningkatan aktivitas penyelenggaraan pendidikan dasar dan menengah di Wilayah III Cirebon, ditandai dengan meningkatnya hasil yang dicapai, mencakup APK, rata-rata nilai UN, rata-rata melanjutkan ke SLA non RSBI dan RSBI, terdapat keeratan hubungan antar faktorfaktor organisasi sekolah dengan hubungan sangat rendah dan moderat, secara simultan, terdapat pengaruh yang signifikan dari semua faktor organisasi sekolah terhadap kompetensi guru. Secara parsial, budaya sekolah memiliki pengaruh paling dominan dibanding yang lainnya, adanya pengaruh yang signifikan dari kompetensi guru terhadap kinerja guru dan terdapat pengaruh yang signifikan dari kinerja guru terhadap kompetensi lulusan.
\end{abstract}

Kata Kunci: faktor organisasi sekolah, kompetensi guru, kinerja guru, kompetensi lulusan SMP. 


\section{PENDAHULUAN}

Sumber daya manusia (SDM) sebagai faktor pendukung suksesnya pencapaian tujuan organisasi, karena dia sebagai inisiator, pelaku proses, serta yang menciptakan budaya organisasi. Dalam sistem pendidikan nasional, guru merupakan faktor kunci penentu keberhasilan pencapaian tujuan pendidikan. Oleh karena itu, dalam upaya meningkatkan kualitas pendidikan secara keseluruhan, diperlukan SDM handal yakni guru profesional yang didukung oleh sejumlah faktor yang melandasinya, seperti kebijakan, kelengkapan sarana prasarana, kepemimpinan kepala sekolah, budaya sekolah, lingkungan masyarakat, lingkungan dunia usaha dan industri, serta faktorfaktor lainnya. Dari sekian banyak faktor pendukung yang ada, manusialah yang paling dominan peranannya, karena sebagus apapun kelengkapan yang dimiliki, tanpa digerakkan oleh manusia yang bertanggungjawab tidak akan berarti apa-apa. Oleh karena itu, keberadaan guru dengan kinerja tinggi menjadi penting.

Untuk memberdayakan faktor-faktor organisasi yang dimiliki sekolah perlu dikelola sebaik-baiknya dengan manajemen yang baik agar tujuan dapat tercapai secara efektif dan efisien. Secara garis besar, pengelolaan yang baik mencakup proses yang berbeda terdiri atas planning, organizing, actuating, dan controlling yang dilakukan untuk mencapai tujuan yang ditentukan dengan menggunakan manusia dan sumber daya lainnya. Berkenaan dengan pemberdayaan manusia, dalam hal ini pendidik (guru), diperlukan manajemen sumber daya manusia (MSDM), yaitu suatu kebijakan dan praktek dalam menentukan sumber daya manusia dalam posisi manajemen, termasuk merekrut, menyaring, melatih, memberi penghargaan, dan melakukan penilaian (Dessler, 2006:5).

Secara teoritis, tugas dan tanggungjawab sebagai guru erat kaitannya dengan kemampuan-kemampuan yang dipersyaratkan untuk memangku jabatan, yakni kompetensi guru. Kompetensi merupakan seperangkat pengetahuan, keterampilkan, dan perilaku tugas yang harus dimiliki. Setelah dimiliki, tentu harus dihayati, dikuasai, dan diwujudkan oleh guru dalam melaksanakan tugas keprofesionalan di dalam mengajar sehingga diharapkan mampu memperlihatkan kinerja yang memadai.
Beberapa penelitian terdahulu terkait dengan kompetensi dan kinerja guru belum secara eksplisit menyebutkan dipengaruhi oleh faktor-faktor organisasi sekolah secara bersamaan. Dengan demikian belum ditemukan penelitian yang memperlakukan faktorfaktor organisasi sekolah seperti budaya organisasi, kepemimpinan kepala sekolah, sarana prasarana, dan kebijakan dalam memprediksi pengaruhnya terhadap kompetensi guru dan dampaknya terhadap kinerja guru serta implikasinya terhadap kompetensi lulusan SMPN di Wilayah III Cirebon.

\section{Budaya Sekolah}

Mengacu pada tiga dan lima tingkatan budaya Hofstede, untuk kategori tiga tingkatan meliputi: universal, kolektif (kelompok), dan individual. Untuk kategori lima tingkatan meliputi: universal, regional, nasional, lokal, dan pribadi. Kemudian, dilihat dari sudut pandang lainnya, Hofstede membagi tiga tingkatan. Ketiganya berkisar antara yang konkret dengan yang abstrak, yaitu: 1) Artifacts, yaitu struktur dan proses organisasional purba yang dapat diamati tetapi sulit ditafsirkan; 2) Es-poused Values, yaitu tujuan, strategi, filsafat; dan 3) Basic underlaying assumptions, yaitu kepercayaan, persepsi, perasaan, dan sebagainya yang menjadi sumber nilai dan tindakan.

Dengan demikian nilai-nilai yang dikembangkan di sekolah tidak dapat dilepaskan dari keberadaan sekolah itu sendiri sebagai organisasi pendidikan yang memiliki peran dan fungsi untuk mengembangkan, melestarikan, dan mewariskan nilai-nilai budaya kepada peserta didik dan seluruh warga sekolah. Nilai-nilai yang telah tertanam kuat pada jiwa seluruh warga sekolah, akan terus dipelihara secara turun temurun sehingga menjadi karakter unik dari sekolah yang bersangkutan. Dimensi-dimensi budaya sekolah dalam penelitian ini diukur melalui enam dimensi, yaitu: 1) obeserved behavioral regularities; 2) norms; 3) dominant values; 4) philosophy; 5) rules; dan 6) organizational climate.

\section{Kepemimpinan Kepala Sekolah}

Kepemimpinan merupakan suatu proses dengan berbagai cara mempengaruhi orang atau sekelompok orang untuk mencapai suatu tujuan bersama. Sering juga disebutkan bahwa kepemimpinan sebagai proses pengaruh, karena inti kepemimpinan adalah mempengaruhi orang lain. Tetapi akhir-akhir ini 
kepemimpinan dilihat juga sebagai manajemen atau pengelola makna (Robbins, 2007:467).

Kepala sekolah merupakan pemimpin formal. Dalam menerapkan peran dan fungsinya sebagai pemimpin formal, kepala sekolah memiliki tanggungjawab penuh untuk mencapai tujuan organisasi. Berkaitan dengan hal tersebut, Mulyasa (2009:84) mengemukakan bahwa sebagai pemimpin formal, kepala sekolah bertanggungjawab atas tercapainya tujuan pendidikan melalui upaya peningkatan profesionalisme tenaga kependidikan ke arah peningkatan prestasi belajar peserta didik. Untuk itu kepala sekolah bertugas melaksanakan fungsifungsi kepemimpinan, baik yang berhubungan dengan pencapaian tujuan pendidikan maupun penciptaan iklim sekolah yang kondusif bagi terlaksananya proses pendidikan secara efektif dan efisien. Dalam hal ini strategi kepemimpinan yang dilaksanakan menjadi sangat penting, karena laju perkembangan kegiatan atau program pendidikan yang ada pada setiap sekolah ditentukan oleh arahan, bimbingan serta visi yang ingin dicapai sekolah. Pengukuran dimensi-dimensi kepemimpinan dalam penelitian ini merujuk pada teori yang dikembangkan Mulyasa (2009:98), dengan demikian variabel kepemimpinan diukur melalui tujuh dimensi, yaitu: 1) edukator, 1) manajer, 3) administrator, 4) supervisor, 5) leader, 6) inovator, dan 7) motivator.

\section{Sarana dan Prasarana}

Sarana adalah segala sesuatu yang dapat dipakai sebagai alat dalam mencapai maksud atau tujuan; alat; media (KBB,2008). Menurut Mulyasa (2004) "Sarana pendidikan adalah peralatan dan perlengkapan yang secara langsung dipergunakan dan menunjang proses pendidikan, khususnya proses belajar, mengajar, seperti gedung, ruang kelas, meja kursi, serta alat-alat dan media pengajaran". Dalam Peraturan Pemerintah Nomor 19 tahun 2005 tentang Standar Pendidikan Nasional, pada ketentuan umum dikemukakan bahwa Standar sarana dan prasarana adalah standar nasional pendidikan yang berkaitan dengan kriteria minimal tentang ruang belajar, tempat berolahraga, tempat beribadah, perpustakaan, laboratorium, bengkel kerja, tempat bermain, tempat berkreasi dan berekreasi, serta sumber belajar lain, yang diperlukan untuk menunjang proses pembelajaran, termasuk penggunaan teknologi informasi dan komunikasi. Pengukuran dimensi-dimensi sarana prasarana dalam penelitian ini merujuk pada PP No. 19 Tahun 2005.
Variabel sarana dan prasarana diukur melalui dua dimensi, yaitu sarana dan prasarana.

\section{Kebijakan}

Kebijakan berarti seperangkat tujuan-tujuan, prinsip-prinsip serta peraturan-peraturan yang membimbing sesuatu organisasi. Kebijakan berfungsi sebagai pedoman untuk bertindak, pembatas prilaku, dan bantuan bagi pengambil keputusan.

Gerakan Wajib Belajar 9 tahun berpijak kuat pada UU No. 20 tahun 2003 tentang Sistem pendidikan Nasional. Penekanan yang lebih dirasakan tampak pada tanggung jawab pembiayaan wajib belajar itu sendiri dan penyelenggaraannya, yaitu pemerintah pusat dan daerah. Program Wajib belajar 9 tahun didasari konsep "pendidikan dasar untuk semua" (universal basic education), yang pada hakekatnya berarti penyediaan akses yang sama untuk semua anak. Melalui program wajib belajar pendidikan dasar 9 tahun diharapkan dapat mengembangkan sikap, pengetahuan, dan keterampilan dasar yang perlu dimiliki semua warga negara.

Dengan wajib belajar anak bangsa dapat menjalani hidup dan menghadapi kehidupan dalam masyarakat. Di samping itu, program Wajib Belajar 9 tahun merangsang aspirasi pendidikan orangtua dan anak yang pada gilirannya diharapkan dapat meningkatkan produktivitas kerja penduduk secara nasional.

Dalam penyelenggaraan Sistem Pendidikan Nasional, terdapat sederet kebijakan, mulai dari UU sampai dengan Surat Keputusan Menteri yang saling memperkuat. Pengukuran dimensi-dimensi kebijakan dalam penelitian ini merujuk pada teori yang dikembangkan Wahab (2000). Variabel kebijakan diukur melalui enam dimensi, yaitu: 1) ketegasan, 2) kejelasan, 3) ketepatan, 4) hambatan, 5) kesempatan, dan 6) fungsi.

\section{Kompetensi Guru}

Dalam UU No 14/2005 tentang Guru dan Dosen, dikemukakan "Kompetensi adalah seperangkat pengetahuan, keterampilan, dan perilaku yang harus dimiliki, dihayati, dan dikuasai oleh guru atau dosen dalam melaksanakan tugas keprofesionalan. Pada Pasal 10 ayat 91, Bab IV, UU No 14 tahun 2005 tentang Guru dan Dosen, diperjelas bahwa kompetensi guru meliputi kompetensi pedagodik, kompetensi kepribadian, kompetensi sosial, dan kompetensi profesional yang diperoleh melalui pendidikan profesi". 
Secara teoritis dijelaskan bahwa kompetensi kinerja profesi keguruan minimal memiliki empat kemampuan, yaitu kemampuan merencanakan proses pembelajaran, melaksanakan dan memimpin/ mengelola proses belajar mengajar, menilai kemajuan proses belajar mengajar, dan menguasai bahan pelajaran. Secara lebih spesifik, dapat dikatakan bahwa kompetensi seseorang mencirikan tindakan/ perilaku serta mahir dalam menjalankan tugas untuk menghasilkan tindakan kerja yang efektif dan efisien (Sagala, 2010).

Pengukuran dimensi-dimensi kompetensi guru dalam penelitian ini merujuk pada teori yang dikembangkan Saud (2009). Variabel kompetensi guru diukur melalui empat dimensi, yaitu: 1) kompetensi pedagogic, 2) kompetensi kepribadian, 3) kompetensi sosial, dan 4) kompetensi profesional.

\section{Kinerja Guru}

Kinerja meliputi beberapa dimensi, yaitu :1) kualitas kerja (quality of work); 2) ketepatan waktu (promptness); 3) inisiatif (initiative); 4) kemampuan (capability) dan 5) komunikasi (communication) (Sedarmayanti (2000:53). Kelima aspek tersebut dapat dijadikan ukuran dalam mengadakan pengkajian tingkat kinerja seseorang. Untuk mengadakan pengukuran terhadap kinerja, ditetapkan "Performance $=$ Ability $x$ Motivation". Dari pernyataan tersebut jelas bahwa untuk mendapatkan gambaran tentang kinerja seseorang diperlukan pengkajian khusus tentang kemampuan dan motivasi.

Kinerja guru memiliki spesifikasi tertentu. Dapat dilihat dan diukur berdasarkan spesifikasi atau kriteria kompetensi yang harus dimiliki oleh setiap guru. Wujud prilaku guru yang menggambarkan kinerjanya adalah kegiatan guru dalam proses pembelajaran, yaitu bagaimana seorang guru merencanakan pembelajaran, melaksanakan kegiatan pembelajaran, dan menilai hasil belajar. Secara konseptual dan umum kinerja guru mencapai tugas aspek kompetensi, yaitu kompetensi profesional, kompetensi sosial, dan kompetensi personal.

Pengukuran dimensi-dimensi kinerja guru dalam penelitian ini merujuk pada teori yang dikembangkan Depdiknas. Variabel kinerja guru diukur melalui empat dimensi, yaitu: perencanaan pembelajaran, pelaksanaan pembelajaran, membuka pembelajaran, dan menutup pembelajaran.

\section{Kompetensi Lulusan}

Kompetensi adalah karakter mendasar seseorang yang menyebabkannya sanggup menunjukkan kinerja efektif atau superior melakukan suatu pekerjaan. (Spencer,1993). Berkenaandengankompetensilulusan, pada Pasal 1 Bab I Ketentuan Umum PP No. 19 Tahun 2005 tentang Standar Nasional Pendidikan kompetensi lulusan adalah "kualifikasi kemampuan lulusan yang mencakup sikap, pengetahuan, dan keterampilan" Secara teoretis "competence is a knowledge, skills, and abilities or capabilities that a person achieves, which become part of his or her being to the extent he or she can satisfactorily perform particular cognitive, affective, and psychomotor behaviors" (Mulyasa, 2003). Dengan demikian, kompetensi diartikan sebagai pengetahuan, keterampilan, dan kemampuan yang dikuasai oleh seseorang yang telah menjadi bagian dari dirinya, sehingga ia dapat melakukan perilaku-perilaku kognitif, afektif, dan psikomotorik dengan sebaik-baiknya.

Pengukuran dimensi-dimensi kompetensi lulusan dalam penelitian ini merujuk pada teori yang dikembangkan Permendiknas No. 23 tahun 2006 tentang SKL. Variabel kompetensi lulusan diukur melalui empat dimensi, yaitu: pengetahuan, kepribadian, akhlak mulia, dan keterampilan untuk hidup mandiri dan mengikuti pendidikan lebih lanjut.

\section{METODE}

Dalam menganalisis dan menginterpretasikan data, digunakan analisis deskriptif dan analisis verifikatif. Analisis deskriptif digunakan untuk menggambarkan karakteristik responden dan variabel penelitian, sedangkan analisis verifikatif digunakan untuk menguji hipotesis penelitian dengan menggunakan uji statistik yang relevan, dalam hal ini digunakan analisis jalur.

Analisis jalur (path analysis) adalah bagian dari model regresi yang dapat digunakan untuk menganalisis hubungan sebab akibat antar satu variabel dengan variabel lainnya. Dalam analisis jalur pengaruh independen dan dependen dapat berupa pengaruh langsung dan pengaruh tidak langsung (direct dan indirect effect), atau dengan kata lain analisis jalur memperhitungkan adanya pengaruh langsung dan tidak langsung. Pengaruh tidak langsung suatu independen variabel terhadap dependen variabel adalah melalui variabel yang lain yang disebut variabel antara (intervening variable). 


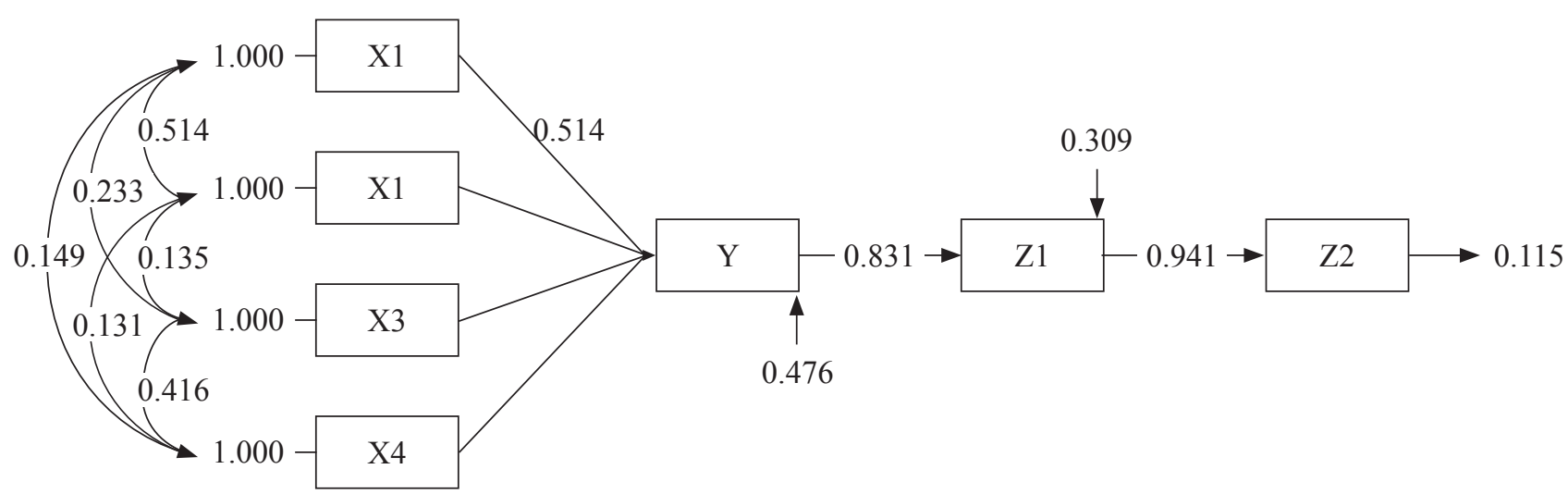

Gambar 1. Analisis Jalur

Untuk menggambarkan hubungan-hubungan kausalitas antar variabel yang akan diteliti pada penelitian ini digunakan diagram jalur (path diagram). Diagram jalur (path diagram) adalah alat untuk melukiskan secara grafis, struktur hubungan kausalitas antar variabel independen, intervening (intermediary) dan variabel dependen.

Skala yang digunakan adalah skala ordinal, sebelum melakukan analisis data penulis mengubah terlebih dahulu data ordinal menjadi data interval dengan menggunakan "Methods Succesive Interval".

Populasi dalam penelitian ini adalah guru SMP Negeri di Wilayah III Cirebon, sedangkan teknik sampling yang digunakan adalah Stratified Random Sampling.

\section{HASIL}

Hasil pengujian terhadap masing-masing pernyataan yang diajukan dari setiap variabel penelitian diperoleh bahwa seluruh item pernyataan dinyatakan valid dan reliabel. Hasil pengujian deskriptif diperoleh bahwa budaya sekolah cukup kondusif, kepemimpinan kepala sekolah baik tetapi meskipun masih terdapat beberapa kelemahan, sarana prasarana juga dalam katagori sedang dan kurang lengkap, sedangkan kebijakan yang ada pada masingmasing SMP di Wilayah III Cirebon ini belum merata, sehingga masih perlu ada peninjauan kembali.

Terdapat pengaruh dari budaya sekolah, kepemimpinan kepala sekolah, sarana prasarana dan kebijakan terhadap kompetensi guru baik secara parsial maupun simultan. Pengaruh yang paling besar terhadap kompetensi guru adalah dari budaya sekolah $(18,49 \%)$, kemudian pengaruh dari kepemimpinan kepala sekolah $(7,29 \%)$, pengaruh dari sarana prasarana $(4,84 \%)$ dan dari kebijakan sebesar $1,69 \%$. Pengaruh kompetensi guru terhadap kinerja guru adalah sebesar 64\%, artinya kinerja guru sangat dominan ditentukan oleh kompetensinya dan kompetensi lulusan SMPN Wilayah III Cirebon ini mutlak (74\%) ditentukan oleh kinerja para gurunya.

Bagaimana hubungan antara variabel-variabel penelitian yang diperoleh dari regresi dengan menggunakan metode analisis jalur digambarkan dalam diagram jalur Gambar 1.

\section{PEMBAHASAN}

Pengujian hipotesis dilakukan dengan menghitung besarnya koefisien jalur dari masingmasing variabel, hasil keseluruhannya dapat dilihat pada Gambar 1. Pada gambar tersebut nampak bahwa terdapat hubungan yang positif dari budaya sekolah, kepemimpinan kepala sekolah, sarana prasarana dan kebijakan, hubungan yang kuat adalah pada hubungan budaya sekolah dengan kepala sekolah, sedangkan yang hubungannya lemah adalah hubungan budaya sekolah dengan kebijakan.

Pengaruh budaya sekolah terhadap kompetensi guru ditemukan hasil yang signifikan (t hitung $>$ t tabel $=7,099>1,98)$. Temuan ini mendukung hipotesis yang menyatakan bahwa budaya sekolah berpengaruh terhadap kompetensi guru. Hasil penelitian ini konsisten dengan teori yang dikemukakan Surya (1997) yang menyatakan budaya yang kondusif akan 
mempunyai pengaruh positif terhadap pengembangan kompetensi guru sebagai pendidik, karena dengan budaya yang kondusif tersebut akan menumbuh kembangkan motif untuk bekerja dengan baik dan produktif. Hal ini sesuai dengan hasil penelitain (MacNeil et al., 2009) yang hasil penelitiannya membuktikan bahwa tingkat pencapaian murid lebih tinggi pada lingkungan sekolah yang baik.

Hasil penelitian lain menunjukkan bahwa mutu persekolahan, tingkat keberhasilan sekolah dalam mencapai tujuan, disiplin sekolah, iklim dan budaya sekolah serta keberhasilan lainnya ditentukan oleh kepemimpinan kepala sekolah (Andreas, K. et al., 2010). Secara empirik terdapat kebiasaan bahwa setiap individu (guru) yang baru memasuki tempat tugasnya, disadariatau tidak akan berusaha beradaptasi dengan budaya yang ada di sekolah tersebut. Apabila budayanya kondusif, maka akan mendorong guru tersebut untuk berusaha mengembangkan kompetensinya secara alami.

Pengaruh kepemimpinan kepala sekolah terhadap kompetensi guru ditemukan hasil yang signifikan ( $\mathrm{t}$ hitung $>\mathrm{t}$ tabel $=5,007>1,98$ ). Temuan ini mendukung hipotesis yang menyatakan bahwa kepemimpinan kepala sekolah berpengaruh terhadap kompetensi guru. Hasil penelitian ini konsisten dengan teori yang dikemukakan Mulyasa (2005:115) yang menyatakan bahwa, keberhasilan kepala sekolah sebagai supervisor antara lain dapat ditunjukkan oleh 1) meningkatnya kesadaran tenaga kependidikan (guru) untuk meningkatkan kinerjanya, dan 2) meningkatnya keterampilan tenaga kependidikan (guru) dalam melaksanakan tugasnya.

Secara empirik juga ditemukan fakta bahwa kepala sekolah memegang peranan penting dalam membimbing dan mengarahkan guru agar terus mengembangkan kompetensinya untuk memenuhi tuntutan keadaan dan profesi. Kepemimpinan kepala sekolah mempunyai pengaruh tidak langsung terhadap efektivitas pendidikan di sekolah melalui gaya kepemimpinannya yang membentuk iklim belajar di sekolah (Hallinger, P., 1996).

Pengaruh sarana prasarana terhadap kompetensi guru, ditemukan hasil yang signifikan ( $\mathrm{t}$ hitung $>$ $\mathrm{t}$ tabel $=3,311>1,98)$. Temuan ini mendukung hipotesis yang diajukan bahwa sarana prasarana berpengaruh terhadap kompetensi guru. Hasil penelitian ini konsisten dengan teori yang dikemukakan Mulyasa (2004) Sarana pendidikan adalah peralatan dan perlengkapan yang secara langsung dipergunakan dan menunjang proses pendidikan, khususnya proses belajar, mengajar, seperti gedung, ruang kelas, ruang guru, meja kursi, serta alat-alat dan media pengajaran. Dengan demikian kompetensi guru akan semakin baik apabila ditunjang dengan sarana dan prasarana yang memadai. Hal ini juga senada hasil penelitian teori Suryosubroto (2004:114) bahwa sarana dan prasarana berfungsi sebagai alat pengajaran, alat peraga dan media pengajaran. Fakta di lapangan menunjukkan bahwa kompetensi guru dapat mudah dikembangkan manakala ditunjang oleh sarana prasarana yang memadai dan ada pada saat dibutuhkan.

Hipotesis yang menyatakan bahwa kebijakan berpengaruh terhadap kompetensi guru, terbukti dengan ditemukan hasil yang signifikan ( $\mathrm{t}$ hitung $>$ $\mathrm{t}$ tabel $=6,287>1,98)$. Hasil penelitian ini konsisten denganteoriyang dikemukakan Syafaruddin(2008:78) bahwa kebijakan dibuat untuk menjadi pedoman dalam bertindak, mengarahkan kegiatan dalam organisasi untuk mencapai tujuan, yang telah ditetapkan. Selain itu, Syafaruddin (2008) juga menyatakan bahwa kebijakan berisi mengenai serangkaian aturan dan peraturan dari para stakeholder demi meningkatnya kompetensi dan kinerja pegawai.

Kebijakan dalam bidang pendidikan, khusunya yang dikeluarkan oleh pemerintah tentunya harus merupakan kebijakan yang memberikan dampak positif bagi peningkatan kompetensi guru-guru di Indonesia. Dalam beberapa penelitian dibahas bahwa adanya intervensi dari pemerintah yang yidak tepat akan membatasi kreativitas guru dan implikasinya akan menhambat proses belajar mengajar itu sendiri (Syahruddin et al., 2013). Dalam penelitian lainnya disebutkan bahwa pemerintah sebagai pemangku kepentingan dan pembuat kebijakan memiliki banyak pekerjaan dalam hal penyusunan konseptual, mempersiapkan, dan mengevaluasi para tenaga pendidik dalam rangka menciptakan tenaga pendidik yang kompeten dan memiliki daya saing global (Kirby, Misty M., dan Crawford, Elizabeth O., 2012).

Di lingkungan pendidikan, khususnya di SMP, yang dimaksud dengan pegawai di antaranya adalah guru. Secara empirik tampak dengan jelas, saat ini dinamika aktifitas guru sangat dinamis, sebagian sibuk memenuhi tuntutan kebijakan tentang kualifikasi ijasah, sebagian yang lain sibuk mengikuti proses sertifikasi, mengikuti kegiatan MGMP bermutu, dan yang lainnya. Kesemuanya itu dampak 
dari diberlakukannya kebijakan baru dalam upaya meningkatkan profesionalisme guru lengkap dengan kompetensinya.

Secara empirik, budaya sekolah dan kepemimpinan kepala sekolah erat kaitannya dengan kompetensi guru, karena budaya yang diciptakan kepala sekolah cenderung mendorong guru untuk berperilaku sesuai kompetensi yang dimiliki, terutama terhadap kompetensi sosial dan kepribadian. Kompetensi pedagogik dan professional banyak ditentukan oleh skill personal masing-masing, namun dalam praktek peningkatannya dapat juga didorong oleh kebijakan yang berlaku bersamaan dengan peran sarana prasarana yang ada. Misalnya kebijakan yang menghendaki agar guru memiliki kualifikasi ijasah S-1, mendorong guru mengikuti pendidikan lanjutan yang secara sadar atau tidak hal tersebut meningkatkan kompetensi pedagogik dan profesional. Demikian juga halnya kebijakan yang menghendaki agar guru menguasai penggunaan teknologi komputer, implementasinya sangat ditentukan oleh memadai atau tidaknya sarana yang dibutuhkan. Dengan demikian, terjadi sinergi antara budaya sekolah, kepemimpinan kepala sekolah, sarana prasarana dan kebijakan dalam meningkatkan kompetensi guru.

Bagaimana pentingnya profesionalitas dan kompetensi pedagogik guru dalam meningkatkan prestasi siswa ditunjukkan oleh hasil penelitian yang dilakukan oleh Rahman (2014). Dalam penelitiannya tersebut disimpulkan bahwa profesionalitas kompetensi pedagogik memberikan dampak positif bagi prestasi siswa di sembilan sekolah menengah pertama yang ada di Ternate. Selain itu, temuan lainnya dari penelitian ini adalah bahwa untuk mencapai kinerja dari para tenaga pendidik, maka diperlukan beberapa program seperti: program pendidikan dan pelatihan, mengaktifkan forum guru, mempersiapkan buku-buku referensi (textbooks), mengoptimalkan pelaksanaan supervisi oleh kepala sekolah, pelatihan strategi mengajar, penggunakan laboratorium ilmu pengetahuan, pelatihan komputer berbasis disain media dan riset terapan.

Hasil penelitian ini juga menemukan bahwa kompetensi berpengaruh terhadap kinerja guru secara signifikan ( $\mathrm{t}$ hitung $>\mathrm{t}$ tabel $=3,311>1,98$ ). Temuan penelitian ini konsisten dengan teori yang dikemukakan oleh Sedarmayanti (2000:53) yang menyatakan bahwa kinerja meliputi beberapa dimensi, yaitu: kualitas kerja (quality of work), ketepatan waktu (promptness), inisiatif (initiative), kemampuan (capability), komunikasi (communication). Kinerja guru dapat dilihat dan diukur berdasarkan spesifikasi atau kriteria kompetensi yang harus dimiliki oleh setiap guru. Wujud perilaku guru yang menggambarkan kinerjanya adalah kegiatan guru dalam proses pembelajaran, yaitu bagaimana seorang guru merencanakan pembelajaran, melaksanakan kegiatan pembelajaran, dan menilai hasil belajar. Jika kompetensi yang dimiliki oleh seseorang itu memadai, maka akan mendorong terciptanya suatu kinerja yang baik.

Kinerja guru berpengaruh secara signifikan terhadap kompetensi lulusan SMPN di Wilayah III Cirebon ( $\mathrm{t}$ hitung $>\mathrm{t}$ tabel $=44,869>1,98$ ). Temuan dari hasil penelitian ini sesuai dengan penelitian Yuhetti (2007) yang menyatakan bahwa guru profesional perlu memiliki sejumlah kompetensi yang dibutuhkan dalam meningkatkan kualitas pendidikan. Dalam konsep pendidikan formal mutu pendidikan tercermin dari prestasi hasil belajar siswa. Untuk mengukur kinerja dan profesionalisme guru perlu dilihat dari kompetensi yang dimilikinya. Dengan semakin baik kinerja guru, akan semakin baik pula mutu pendidikan yang direpresentasikan melalui lulusan yang kompeten. Kondisi demikian, sejalan dengan hasil beberapa penelitian sebelumnya dari, Bangbade (2004), Akiri (2013), Kumar (2013) serta Arifin (2013) yang hasil penelitiannya menyimpulkan bahwa dengan semakin baiknya kinerja guru akan berdampak positif pada mutu atau kualitas lulusan.

Dalam lampiran Peraturan Menteri Pendidikan Nasional Nomor 23 tahun 2006 terdapat penjelasan bahwa Standar Kompetensi lulusan Satuan Pendidikan (SKL-SP) dikembangkan berdasarkan tujuan setiap satuan pendidikan sehingga kinerja guru berperan besar dalam upaya pencapaian satuan pendidikan.

Secara empirik, upaya mencapai tujuan pendidikan secara keseluruhan, pada hakikatnya terletak pada keberhasilan guru dalam melakukan proses pembelajaran sehingga kompeten tidaknya lulusan SMPN di Wilayah III Cirebon tergantung kepada kinerja guru dalam mengelola kelas dan pembelajaran. Dengan kata lain, kinerja guru merupakan faktor kunci penentu keberhasilan dalam mencapai tujuan pendidikan di satuan pendidikan tertentu, meskipun bukan satu-satunya faktor yang berpengaruh. Ungkapan ini sejalan dengan kebijakan pemerintah yang tertuang dalam Undang-undang 
No. 14 tahun 2005 tentang Guru dan Dosen yang secara khusus memperhatikan profesionalisme guru diimbangi dengan upaya peningkatan kesejahteraannya. Intinya, pemerintah paham betul bahwa keberadaan guru sangat strategis dalam upaya mencapai tujuan pendidikan.

\section{KESIMPULAN}

Dari hasil analisis pengaruh, baik secara parsial maupun simultan, budaya sekolah, kepemimpinan kepala sekolah, sarana dan prasarana, dan kebijakan berpengaruh signifikan terhadap kompetensi guru. Apabila dibandingkan, ternyata budaya sekolah memiliki pengaruh yang lebih besar, hal ini terjadi karena di SMP Negeri terdapat budaya yang di dalamnya terdapat nilai-nilai dan keyakinan yang dapat mendorong guru untuk mengembangkan kompetensinya secara terus menerus. Kepala sekolah tidak selamanya berhubungan langsung dengan guru, demikian juga sarana dan prasarana hanya sebagai pendukung, dan kebijakan hanya merupakan acuan bertindak. Di samping itu, peran kepemimpinan, dukungan sarana dan arahan dari kebijakan merupakan unsur-unsur pembentuk budaya. Kompetensi guru secara signifikan berdampak pada kinerja guru. Kinerja guru berpengaruh signifikan terhadap kompetensi lulusan SMPN di Wilayah III Cirebon.

\section{DAFTAR PUSTAKA}

Andreas, K. et al. 2010. The Influence of School Leadership Styles and Culture on Students' Achievement in Cyprus Primary Schools. Journal of Educational Administration, 48(2): 218-240.

Akiri, Agharuwhe A. 2013. Effects of Teachers'Effectiveness on Students'Academic Performance in Public Secondary Schools; Delta State - Nigeria. Journal of Educational and Social Research, 3(3): 105-111.

Arifin, H. M. 2013. The Influence of Competence and External Motivation Factor toward Teachers Working Performance in Jayapura - Papua Indonesia. Journal of Business and Management, 7(5): 01-07.

Bangbade, J. O. 2004. Effects of subject matter knowledge in the teaching and learning of Biology and Physic. Teaching and Teacher Education.

Dessler, Gary, 2008. Human Resource Management (13 ${ }^{\text {th }}$ Edition). New Jersey: Person Educational.
Hallinger, P., Bickman, L., \& Davis, Ken. School Context, Principal Leadership, and Student Reading Achievement. The Elementary School Journal, 96(5): 527-549.

MacNeil, A. J., Preter, D. L., Busch, S. 2009. The effects of school culture and climate on student achievement. International Journal of Leadership in Education: Theory and Practice, 12(1).

Mulyasa, E. 2004. Manajemen Berbasis Sekolah; Konsep, Strategi, dan Implementasi, Bandung: Remaja Rosda Karya.

Kirby, M. M. \& Crawford, E. O. 2012. The Preparation of Globally Competent Teachers: A Comparison of American and Australian Education Policies and Perspectives. Global Partners in Education Journal, 2(1): 12-24.

Kumar, Vijay, M. S. 2013. The Influence of Teacher's Professional Competence on Students'Achievement. Journal of Engineering, 3(1): 12-18.

Rahman, M. H. 2014. Professional Competence, Pedagogical Competence and The Performance of Junior High School of Science Teachers. Journal of Education and Practice, 5(9): 75-80.

Sagala, Syaiful. 2000. Manajemen Berbasis Sekolah dan Masyarakat, Jakarta: Nimas Multia.

Sedarmayanti, 2000. Tata Kerja dan Produktivitas Kerja, Bandung: Mandar Maju.

Saud, Saefudin. 2008. Pengembangan Profesi Guru, Bandung: Alfabeta.

Spencer, M. L. \& Spencer, M. S. 1993. Competence at Work: Models for Superrior Performance. New York: John Wily \& Son.

Syafaruddin. 2008. Efektivitas Kebijakan Pendidikan; Konsep, Strategi, dan Aplikasi Kebijakan Menuju Organisasi Sekolah Efektif. Jakarta: Rineka Cipta.

Syahruddin, Andi Ernawati, Muh. Nasir Ede. 2013. Teachers' Pedagogical Competence in SchoolBased Management. Journal of Education and Learning, 7(4): 213-218.

Surya, H. M. 1997. Peningkatan Profesionalisme Guru Menghadapi Pendidikan Abad ke-21. Suara Guru, 7: 15-17.

Suryosubroto. 2004. Manajemen Pendidikan di Sekolah, Jakarta: Rineka Cipta.

Yuhetty dan Miarso, Y. 2007. Kajian Kompetensi Guru dalam Meningkatkan Mutu Pendidikan, Jakarta: Mendiknas Bidang Mutu Pendidikan. Diunduh dari http://yusufhadi.net/kompetensiguru-dalam-meningkatkan-mutu-pendidikan. File tersedia (online). 